Lộc ${ }^{(5)}$ là $86 \%$.

Hạn chế của đề tài. Việc sử dụng thiết kế nghiên cứu cắt ngang, không phải là thiết kế cho năng lực mẫu mạnh làm hạn chế khả năng khảo sát mức độ liên quan nhân quả giữa các yếu tố.

\section{KẾT LUÂNN}

Trong thời gian 7 tháng thực hiện nghiên cứu trên 332 thai phụ có tuổi thai đủ 37 tuân trở lên tại TTYT Huyện Xuân Lộc, chúng tôi ghi nhận được:

Tỷ lệ thai phụ đi khám thai tối thiểu 4 lân trong thai kỳ là 86,4\%.

Tỷ lệ thai phụ có kiến thức tốt về các nội dung CSTS là $89,5 \%$.

Tỷ lệ thai phụ thực hành đúng các nội dung về CSTS là $87,6 \%$.

\section{TÀI LIÊU THAM KHẢO}

1. WHO, (2019), Trends in maternal mortality 2000 to 2017: estimates by WHO, UNICEF, UNFPA.

2. UNICEF, (2019), The state of the world's children 2019: children, food and nutrition, New York.

3. Tổng cục Thống kê, UNICEF, (2015), Điều tra đánh giá các mục tiêu trẻ em và phụ nữ Việt Nam 2014, Báo cáo cuối cùng, Hà Nội.
4. Phạm Văn Dậu, Phạm Câm Kỳ, Bùi Thị Hương, (2021), "Thực trạng kiến thức và thực hành làm me an toàn của các bà me sinh con tai cơ sở y tế công trên địa bàn tỉnh Ninh Bình năm 2019", Tap chí Y hoc Cônng đồng, 62 (1), 146-151.

5. Ngô Viểt Lộc, Lế Thị Thanh Huyên, (2017), "Kiến thức vâ thực hành về chăm sóc thai sản tai huyện Hòa Vang, thành phố Đà Nẵng năm 2015", Tap chí Y học Thành phố Hồ Chí Minh, 21 (1), 49-53.

6. Mai Thi Kim Thanh, (2017), "Kiến thức thực hành chăm sóc trước sinh của các bà me có con nhỏ dưới 1 tuổi tại huyện Buôn Đôn và Cư Kuin tỉnh Đắk Lắk năm 2016", Tạp chí Y học Việt Nam.

7. Sitalakshmi $\mathbf{V}$, Bavyasri $P$, Talapala $R$, Kopperla M, (2020), "Study on knowledge, attitude and practice of ante-natal care among pregnant women attending antenatal tertiary care institution", International Journal of Reproduction, Contraception, Obstetrics and Gynecology; Vol 9, No 3 (2020): March 2020.

8. Ogunba B O, Abiodun O B, (2017), "Knowledge and attitude of women and its influence on antenatal care attendance in Southwestern Nigeria", J Nutr Health Sci, 4 (2), pp. 207.

9. Nguyển Thị Mỹ Hương, Châu Khắc Tú, Trân Thị Lệ Hà, Ngô Hoàng Hiếu, (2015), "Đánh giá tình hỉnh chăm sóc trước sinh của các sản phu đến sinh tại Khoa Phụ Sản Bệnh viện Trung ương Huế", Tạp chí Phụ sản, 13 (3), 76-78.

\title{
ĐÁNH GIÁ HIÊUU QUẢ KÉO DÀI GIẢM ĐAU SAU MỔ LẤY THAI BẰNG GÂY TÊ MẠT PHẲNG CO' NGANG BUUNG BẰNG HỖN HỢP THUỐC ROPIVACAIN PHỐI HỢP VỚI DEXAMETHASON
}

\section{Nguyễn Thị Thùy Dương ${ }^{1}$, Nguyễn Đức Lam $^{2}$, Nguyễn Thị Thanh ${ }^{3}$}

\section{TÓM TẮT}

Một nghiên cứu thử nghiệm lâm sàng ngẫu nhiên có đối chứng được thực hiện nhằm đánh giá hiệu quả kéo dài giảm đau sau mố lấx thai bằng gây tê mặt phẳng cơ ngang bung bằng hôn hợp thuốc ropivacain phối hợp với dexamethason. Nghiên cứu được thực hiên trền 100 bênh nhân tại Bênh viên Phu sản Hà Nội. Kết quả nghiên cứu cho thấy, thời gian giải cứu cớn đau đâu tiên ngắn hơn đáng kể ở nhóm $1(11,01$ $\pm 3,62$ giờ) so với nhóm $2(18,54 \pm 4,15$ giờ $)(p<0,05)$. Tổng nhu cầu morphin trong 24 giờ đâu sau phẩu thuật cao hơn đáng kể ở nhóm $1(5,62 \pm 2,1 \mathrm{mg})$ so với nhóm $2(4,07 \pm 1,9 \mathrm{mg})(\mathrm{p}<0,05)$. Điểm số VAS- $S$ và VAS- $V$ của cả hai nhóm khác nhau không đáng kể tại các thời điểm 1 giờ, 2 giờ và 4 giờ sau phấu thuật,

${ }^{1}$ Bênh viên Sản Nhi Lào Cai

2Trường Đại học Y Hà Nội

${ }^{3}$ Trung tâm Y tế Từ Sơn, Bắc Ninh

Chịu trách nhiệm chính: Nguyễn Thị Thùy Dương

Email: thuyduonggaymelaocai@gmail.com

Ngày nhận bài: 10.8.2021

Ngày phản biện khoa học: 11.10.2021

Ngày duyệt bài: 19.10.2021 tuy nhiên ở nhóm 1 cao hơn đáng kể so với nhóm 2 tai các thời điểm 8 giờ, 12 giờ, 16 giờ và 24 giờ sau phẫu thuật.Tỷ lệ nôn ở nhóm 1 chiếm $20 \%$ cao hơn nhiêuu so với nhóm 2 chỉ chiếm $4 \%, \mathrm{p}<0,05$. Các chì số lâm sàng liên quan đến tuần hoàn trong giới hạn bình thường và tương đương nhau giữa hai nhóm ở các thời điếm 1 giờ, 2 giờ , 4 giờ nghiên cứu. Nhịp tim, huyết áp trung bình lúc 8 giờ, 12 giờ, 16 giờ và 24 giớ sau phâu thuất ở nhóm 1 cao hơn đáng kể so với bệnh nhân nhóm $2(p<0,05)$. Các chỉ số lầm sàng liên quan đến hô hấp trong giới hạn bình thường và tương đương nhau giữa hai nhóm ở tất cả các thời điểm nghiên cứu. Trong nghiên cứu của chúng tôi không gặp bất kỳ tai biến nào liên quan đến gây tê TAP block.

Tư khóa: giảm đau, mổ lấy thai, ropivacain, dexamethason

\section{SUMMARY}

EVALUATION OF THE LONG-TERM

EFFECTIVENESS OF ANALGESIA AFTER CESAREAN SECTION BY LOCAL ANESTHESIA OF THE TRANSVERSE ABDOMINIS MUSCLE WITH A COMBINATION OF ROPIVACAINE AND DEXAMETHASONE 
A randomized controlled clinical trial was conducted to evaluate the long-term efficacy of postcesarean section analgesia at transverse abdominis muscle with a combination of ropivacaine plus dexamethasone. The study was conducted on 100 patients at Hanoi Obstetrics and Gynecology Hospital. Results showed that the first rescue analgesic was significantly shorter in group 1 (11.01 \pm 3.62 hours) compared to group $2(18.54 \pm 4.15$ hours $)(p<0.05)$. Total morphine requirement in the first 24 hours after surgery was significantly higher in group 1 (5.62 \pm 2.1 $\mathrm{mg})$ than in group $2(4.07 \pm 1.9 \mathrm{mg})(p<0.05)$. VAS-S and VAS-V scores of both groups were not significantly different at 1 hour, 2 hours and 4 hours after surgery, however, the score in group 1 was significantly higher than group 2 after 8 hours, 12 hours, 16 hours and 24 hours after surgery. The rate of vomiting in group 1 accounted for $20 \%$ which was much higher than group 2 with only $4 \%, p<0.05$. The clinical indices related to circulation were within normal limits and were similar between the two groups at 1 hour, 2 hours, and 4 hours of the study. Mean heart rate, blood pressure at 8 hours, 12 hours, 16 hours and 24 hours after surgery were significantly higher in group 1 than in group 2 patients $(p<0.05)$. The clinical parameters related to respiration were within normal limits and were similar between the two groups at all study time points. In our study, there were no complications related to TAP block anesthesia.

Keywords: analgesia, cesarean section, ropivacaine, dexamethasone

\section{I. ĐẶT VẤN ĐỀ}

Phương pháp vô cảm chính cho mổ lấy thai là gây tê tủy sống vì tính hiệu quả vô cảm và giãn cơ tốt, tránh được những nguy cơ của gây mê toàn thân cho me và thai nhi, ngoài ra khi sử dụng thuốc tê phối hợp với gây tê tủy sống còn có tác dung giảm đau sau mổ tốt. Đau sau mổ lấy thai ảnh hưởng rất lớn đến tâm sinh lý cũng như sự phục hồi của sản phụ[1], sự gắn kết của sản phụ với con, ảnh hưởng đến thời gian cho con bú $[2,3]$.

Gây tê mặt phẳng cơ ngang bụng (Transverse Abdominis Plane Block) viết tắt là TAP block là kỹ thuật đưa một lượng thuốc tê tập trung vào mặt phẳng giữa cơ chéo bung trong và cơ ngang bụng nơi mà các sợi thần kinh đốt sống đi qua mặt phẳng này [4]. TAP block được xem như một phương pháp trong giảm đau đa mô thức hiệu quả và ngày càng được khuyến khích trong thực hành lâm sàng. Vấn đề đang được quan tâm nhiêu hiện nay là việc phối hợp thuốc trong gây tê vùng. Mục đích của việc phổi hợp thuốc là để tăng thời gian vô cảm cho phẫu thuât, tăng thời gian giảm đau sau mổ và giảm liều thuốc tê cần dùng. Đã có rất nhiều thuốc đã được nghiên cứu để trộn với thuốc tê như clonidin, opioid, tramadol... Có một thuốc mà hiện tại đang rất quan tâm là dexamethason trong việc phối hợp với thuốc tê để kéo dài thời gian giảm đau sau mổ $[5,6]$. Trên thế giới đã có nhiều nghiên cứu chỉ ra rằng, khi phối hợp dexamethason với thuốc tê làm tăng thời gian giảm đau sau mổ cho bệnh nhân và giảm lượng tiêu thụ opioid sau mổ của những bênh nhân đó. Tai Việt Nam hiện nay chưa có nhiều nghiên cứu về vấn đề này. Vì vây chúng tôi tiến hành nghiên cứu này nhằm "Đánh giá hiệu quả kéo dài giảm đau sau mổ lây thai bằng gây tê mặt phẳng cơ ngang bụng bằng hỗn hợp thuốc ropivacain phôi hợp với dexamethason".

\section{II. ĐỐI TƯợNG VÀ PHƯƠNG PHÁP NGHIÊN CỨU 2.1 Đối tượng nghiên cứu: \\ Tiêu chuấn lựa chọn: Sản phụ mổ lấy thai} được vô cảm bằng gây tê tủy sống; Đường mô Pfannenstiel (Rạch ngang trên khớp vệ); Bệnh nhân từ 18 - 40 tuổi; ASA I, II .

Tiêu chuẩn loại trừ bệnh nhân: Các chống chỉ định của gây tê vùng: Dị ứng thuốc tê,rối loạn đông máu, nhiễm trùng vùng chọc kim...; Có chống chỉ định của dexamethasone: Đái tháo đường, loét dạ dày tiến triển...; Có các bệnh lý khác: Nội khoa, sản khoa; Bệnh nhân không đồng ý tham gia vào nghiên cứu.

Tiêu chuẩn đưa ra khỏi nghiên cứu: Bệnh nhân không muốn tiếp tục tham gia nghiên cứu; Bệnh nhân có biến chứng của phẫu thuật hoặc gẩy tê; Sản phụ đã làm giảm đau trong chuyển dạ bằng gây tê ngoài màng cứng.

2.2 Thời gian và địa điểm nghiên cứu: Nghiên cứu được tiến hành tại Khoa Gây mê Hồi sức Bệnh viện Phụ sản Hà Nội từ tháng 10/2020 đển tháng 8/2021.

2.3 Thiết kế nghiên cứu: nghiên cứu tiến cứu, lâm sàng, ngẫu nhiên có đối chứng.

2.4 Cỡ mấu và chọn mẫu: Lây mẫu thuận tiện 100 bệnh nhân. Chọn mẫu phân nhóm bằng bốc thăm ngẫu nhiên.Cả 2 nhóm đều được giảm đau sau mổ bằng gây tê mặt phẳng cở ngang bụng (TAP block) dưới hướng dẫn của siêu âm.

Nhóm 1 (nhóm ropivacaine) n1 = 50bệnh nhân: Bệnh nhân sẽ được giảm đau sau mổ gây tê mặt phẳng cơ ngang bụng bằng thuốc ropivacaine.

Nhóm 2 (nhóm ropivacaine với dexamethason) n2 = 50 bệnh nhân: Bệnh nhân sẽ được giảm đau sau mổ gây tê mặt phẳng cơ ngang bụng bằng thuốc ropivacaine với dexamethason

2.5 Cách thức thu thập thông tin: Số liệu được thu thập ở các thời điểm khác nhau và ghi lại trong mấu bệnh án nghiên cứu theo trình tự thời gian như sau:

Trước gây tê: thu thập các số liệu về đặc 
điểm chung của bệnh nhân nghiên cứu, bao gồm tuổi, giới, cân nặng, nghề nghiệp, tiền sử mổ lấy thai, phân loại sức khoẻ theo ASA; các yếu tố tiền sử liên quan đến đối tượng nghiên cứu; các xét nghiệm về công thức máu, đông máu; tuổi thai.

Trong mổ: thu thập số liệu liên quan đến gâay tê (thuốc sử dụng, liểu lượng, thời gian) và phẫu thuật (thời gian mổ).

Sau mổ: thu thập số liệu về điểm VAS, tiêu thụ giảm đau, thay đổi về hô hấp, tuần hoàn và các tác dụng không mong muốn, mức độ thỏa mãn về giảm đau, tỷ lệ nôn và buốn nôn.

Thời điểm đánh giá được xác định cụ thể như sau: $\mathrm{H} 1, \mathrm{H} 2, \mathrm{H} 4, \mathrm{H} 8, \mathrm{H} 12, \mathrm{H} 16, \mathrm{H} 24$ tương ứng sau khi giảm đau 1, 2, 4, 8, 12, 16, 24 giờ.

2.6 Phân tích số liệu: Các số liệu nghiên cứu được phân tích, xử lý theo phần mềm SPSS 20.0. Các biến định lượng được mô tả dưới dạng trung bình $(X)$ và độ lệch chuẩn $(S D)$. Các biến định tính được mô tả dưới dạng tỷ lệ (\%). Để so sánh sự khác biệt giữa các tỷ lệ (biến định tính) dùng test khi bình phương $\left(\chi^{2}\right)$. So sánh sự khác biệt giữa các giá trị trung bình (biến định lượng): sử dụng test $T$ - Student khi so sánh 2 nhóm và test ANOVA khi so sánh trên 2 nhóm. Khác biệt được coi là có ý nghĩa thống kê khi $p<0,05$.

2.7 Đạo đức nghiên cứu: Đề tài nghiên cứu đã được thông qua hội đồng khoa học của Trường Đại học Y Hà Nội, hội đồng khoa học của Bênh viện Phụ sản Hà Nôii và được phép thực hiện tại khoa Gây mê - Hồi sức Bệnh viện Phụ sản Hà Nội.

\section{KẾT QUẢ NGHIÊN CỨU}

Nghiên cứu 100 sản phụ sau mổ lấy thai bằng phương pháp gây tê tủy sống được làm giảm đau bằng gây tê TAP block chia 2 nhóm: Nhóm 1 dùng ropivacaine $0,375 \%$; nhóm 2 dùng ropivacaine $0,375 \%+8 \mathrm{mg}$ dexamethasone. Cả 2 nhóm đều được dùng một viên Diclofenac 100 $\mathrm{mg}$ đặt hậu môn là phương pháp giảm đau đa phương thức. Kết quả cho thấy:

Tuổi trung bình của bênh nhân trong nhóm 1 là $31,34 \pm 5,54$ (thấp nhất là 21 tuổi và cao nhất 45 tuổi), trong nhóm 2 trung bình là 30,15 \pm
5,50 tuổi (thấp nhất là 22 tuổi và cao nhất 39 tuổi). Tuổi thai trung bình của bệnh nhân trong nhóm chứng và nhóm TAPB lần lượt là 38,05 \pm 1,80 tuần và $37,83 \pm 1,66$ tuần.

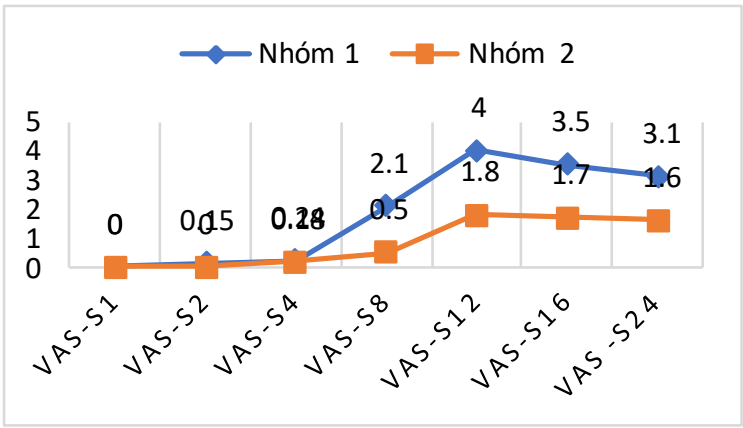

Biểu đồ 1. Điểm VAS -S cho cơn đau thành bụng

Biểu đồ 1 cho thây sự khác biệt về điểm số VAS- $\mathrm{S}$ của cả hai nhóm là không đáng kể tại các thời điểm 1 giờ, 2 giờ và 4 giờ sau phẫu thuật. Điểm số VAS -S ở nhóm 1 cao hơn đáng kể so với nhóm 2 ở 8 giờ, 12 giờ, 16 giờ và 24 giờ sau phẫu thuật, sự khác biệt có ý nghĩa thống kê (p $<0,05$ ).

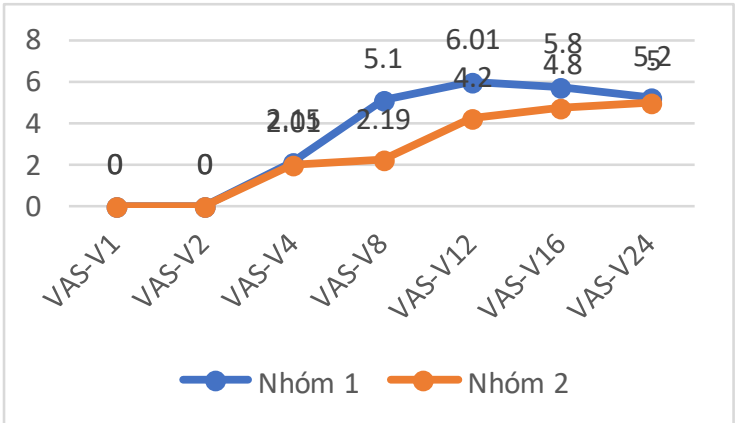

Biểu đồ 2. Điểm VAS -S cho cơn đau tạng

Biểu đồ 2 cho thấy sự khác biệt về điểm sốVAS- $V$ của cả hai nhóm là không đáng kể tại các thời điểm 1 giờ, 2 giờ và 4 giờ sau phấu thuật. Điểm số VAS -V ở nhóm 1 cao hơn đáng kể so với nhóm 2 ở 8 giờ, 12 giờ, 16 giờ và 24 giờ sau phẫu thuật, sự khác biệt có ý nghĩa thống kê $(p<0,05)$.

Bảng 1. Nhu câu thuốc giảm đau, Mức độ hài lòng của bệnh nhân với giảm đau

\begin{tabular}{|c|c|c|c|}
\hline & Nhóm 1(n $1, \%)$ & Nhóm 2(n2, \%) & $\mathbf{p}$ \\
\hline \multicolumn{4}{|l|}{ Nhu câu thuốc giảm đau } \\
\hline Thời gian đế giải cứu cơn đau đầu tiên & $11,58 \pm 3,75$ giờ & $19,01 \pm 3,85$ giờ & $<0,05$ \\
\hline Số lượng Morphin tiêu thụ trong 24 giờ & $3,85 \pm 1,10 \mathrm{mg}$ & $2,05 \pm 1,25 \mathrm{mg}$ & $<0,05$ \\
\hline Mức độ hà̀i lòng: Rấ & $40(80 \%)$ & $45(90 \%)$ & $<0,05$ \\
\hline Hài lòng & $10(20 \%)$ & $5(10 \%)$ & $<0,05$ \\
\hline Không hài lòng & 0 & 0 & $>0,05$ \\
\hline Có hiệu quả chống nồn & $10(20 \%)$ & $2(4 \%)$ & $<0,05$ \\
\hline
\end{tabular}


Bảng 1 cho thấy thời gian yêu cầu thuốc giảm đau đầu tiên ở nhóm 1 và nhóm 2 lần lượt là 11,58 $\pm 3,75 ; 19,01 \pm 3,85$, sự khác biệt có ý nghĩa thống kê $(p<0,05)$. Số lượng Morphin tiêu thụ trong 24 giờ ở nhóm 1 và nhóm 2 lần lượt là $3,85 \pm 1,10 ; 2,05 \pm 1,25$, sự khác biệt có ý nghĩa thống kê ( $p$ $<0,05)$. Cả 2 nhóm đều có mức độ hài lòng và rất hài lòng là chủ yếu, không có trường hợp nào bệnh nhân không hài lòng.Nhóm 2 có tỉ lệ rất hài lòng và hài lòng lân lượt là $90 \%$ và $10 \%$ trong khi đó nhóm 1 có tỉ lệ hài lòng $80 \%$ và rất hài lòng là $20 \%$, sự khác biệtnày có ý nghĩa thống kê với $p<$ 0,05.Tỷ lệ nôn ở nhóm 1 chiếm $20 \%$ cao hơn nhiêu so với nhóm 2 chỉ chiếm $4 \%(p<0,05)$.

\section{Bảng 2. Tân số tim (lần/phút), huyêt áp trung bình ( $\mathrm{mmHg}$ ) các thời điểm}

\begin{tabular}{|c|c|c|c|c|}
\hline Thời điểm & Nhóm & $\begin{array}{l}\text { Nhóm 1 } \\
\left(X_{ \pm S D}\right)\end{array}$ & $\begin{array}{c}\text { Nhóm } 2 \\
\left(X_{ \pm} \text {SD) }\right.\end{array}$ & p \\
\hline \multirow[b]{2}{*}{$\mathrm{H}_{1}$} & Tần số tim & $78,82 \pm 8,6$ & $80,87 \pm 7,0$ & \multirow{2}{*}{$>0,05$} \\
\hline & HATB & $79,43 \pm 6,1$ & $79,03 \pm 6,5$ & \\
\hline \multirow[b]{2}{*}{$\mathrm{H}_{2}$} & Tần số tim & $79,10 \pm 5,1$ & $81,62 \pm 4,7$ & \multirow{2}{*}{$>0,05$} \\
\hline & HATB & $80,03 \pm 5,8$ & $79,47 \pm 5,5$ & \\
\hline \multirow[b]{2}{*}{$\mathrm{H}_{4}$} & Tân số tim & $84,57 \pm 4,5$ & $83,40 \pm 4,7$ & \multirow{2}{*}{$>0,05$} \\
\hline & HATB & $82,05 \pm 5,5$ & $81,45 \pm 4,8$ & \\
\hline \multirow{2}{*}{$\mathrm{H}_{8}$} & Tần số tim & $95,80 \pm 5,5$ & $84,42 \pm 5,0$ & \multirow{2}{*}{$<0,05$} \\
\hline & HATB & $86,78 \pm 4,7$ & $82,01 \pm 4,1$ & \\
\hline \multirow{2}{*}{$\mathrm{H}_{12}$} & Tần số tim & $100,02 \pm 4,9$ & $89,89 \pm 4,9$ & \multirow{2}{*}{$<0,05$} \\
\hline & HATB & $88,50 \pm 4,4$ & $81,58 \pm 4,4$ & \\
\hline \multirow{2}{*}{$\mathrm{H}_{16}$} & Tần số tim & $96,45 \pm 5,0$ & $86,20 \pm 5,2$ & \multirow{2}{*}{$<0,05$} \\
\hline & HATB & $87,45 \pm 4,2$ & $81,02 \pm 3,8$ & \\
\hline \multirow{2}{*}{$\mathrm{H}_{24}$} & Tần số tim & $93,57 \pm 4,3$ & $85,73 \pm 4,2$ & \multirow{2}{*}{$<0,05$} \\
\hline & HATB & $88,10 \pm 4,6$ & $80,27 \pm 3,9$ & \\
\hline
\end{tabular}

Kết quả bảng 2 cho thấy, nhịp tim tại thời điểm $\mathrm{H1}, \mathrm{H} 2$, $\mathrm{H} 4$ có giá trị trung bình tương đương nhau ở cả hai nhóm, sự khác biệt không có ý nghĩa thống kê $(p>0,05)$. Tại các thời điểm $H 8$, $\mathrm{H} 12, \mathrm{H} 16, \mathrm{H} 24$ nhịp tim ở nhóm 1 cao hơn so với nhóm 2, sự khác biệt có ý nghĩa thông kê ( $\mathrm{p}<$ $0,05)$. Huyết áp trung bình tại thời điểm $\mathrm{H1}, \mathrm{H} 2, \mathrm{H} 4$ ở 2 nhóm là tương đương nhau, sự khác biệt không có ý nghĩa thống kê ( $p>0,05)$.Huyết áp trung bình tại các thời điểm H8, H12,H16, H24 nhịp tim ở nhóm 1 cao hơnso với nhóm 2 , sự khác biệt có ý nghĩa thống kê $(p<0,05)$.

Bảng 3. Tân số thở trung bình (î̉n/phút) và $\mathrm{SpO}_{2}(\%)$ tại các thời điểm

\begin{tabular}{|c|c|c|c|c|}
\hline Thời điểm & Nhóm & $\begin{array}{l}\text { Nhóm 1 } \\
\left(X_{ \pm} \text {SD) }\right.\end{array}$ & $\begin{array}{c}\text { Nhóm } 2 \\
\left(X_{ \pm} \text {SD) }\right.\end{array}$ & $\mathbf{p}$ \\
\hline \multirow{2}{*}{$\mathrm{H}_{1}$} & Tân số thở & $18,87 \pm 1,3$ & $18,77 \pm 1,4$ & \multirow[b]{2}{*}{$>0,05$} \\
\hline & $\mathrm{SpO}_{2}$ & $99,63 \pm 0,5$ & $99,80 \pm 0,4$ & \\
\hline \multirow[b]{2}{*}{$\mathrm{H}_{2}$} & Tần số thở & $18,87 \pm 1,4$ & $18,67 \pm 1,4$ & \multirow{2}{*}{$>0,05$} \\
\hline & $\mathrm{SpO}_{2}$ & $99,27 \pm 0,5$ & $99,47 \pm 0,6$ & \\
\hline \multirow{2}{*}{$\mathrm{H}_{4}$} & Tân số thở & $18,70 \pm 1,3$ & $18,60 \pm 1,3$ & \multirow[b]{2}{*}{$>0,05$} \\
\hline & $\mathrm{SpO}_{2}$ & $98,43 \pm 0,5$ & $98,37 \pm 0,5$ & \\
\hline \multirow[b]{2}{*}{$\mathrm{H}_{6}$} & Tân số thở & $18,77 \pm 1,0$ & $18,57 \pm 1,3$ & \multirow{2}{*}{$>0,05$} \\
\hline & $\mathrm{SpO}_{2}$ & $98,37 \pm 0,6$ & $98,33 \pm 0,5$ & \\
\hline \multirow[b]{2}{*}{$\mathrm{H}_{8}$} & Tân số thở & $18,50 \pm 1,0$ & $18,43 \pm 1,4$ & \multirow{2}{*}{$>0,05$} \\
\hline & $\mathrm{SpO}_{2}$ & $98,17 \pm 0,6$ & $98,20 \pm 0,6$ & \\
\hline \multirow{2}{*}{$\mathrm{H}_{12}$} & Tân số thở & $18,63 \pm 1,1$ & $18,40 \pm 1,3$ & \multirow{2}{*}{$>0,05$} \\
\hline & $\mathrm{SpO}_{2}$ & $98,27 \pm 0,7$ & $98,30 \pm 0,5$ & \\
\hline \multirow{2}{*}{$\mathrm{H}_{16}$} & Tân số thở & $18,57 \pm 1,2$ & $18,53 \pm 1,1$ & \multirow{2}{*}{$>0,05$} \\
\hline & $\mathrm{SpO}_{2}$ & $98,33 \pm 0,6$ & $98,23 \pm 0,5$ & \\
\hline \multirow{2}{*}{$\mathrm{H}_{24}$} & Tần số thở & $18,77 \pm 1,1$ & $18,67 \pm 1,1$ & \multirow{2}{*}{$>0,05$} \\
\hline & $\mathrm{SpO}_{2}$ & $98,37 \pm 0,6$ & $98,33 \pm 0,5$ & \\
\hline
\end{tabular}

Kết quả bảng 3 cho thấy tần số thở và $\mathrm{SpO}_{2}$ thấp nhất là $96 \%$ ). Không có khác biệt ý nghĩa trung bình của tất cả bệnh nhân trong nghiên cứu tại các thời điểm đánh giá đều trong giới hạn bình thường (tần số thở giá trị cao nhất là 22 lần/phút và thấp nhất là 15 lần/phút, $\mathrm{SpO}_{2}$ giữ̃a 2 nhóm về tần số thở và $\mathrm{SpO}_{2}$ trung bình ở mỗi thời điểm đánh giá $(p>0,05)$. Không gặp bệnh nhân ngừng thở hoặc có tần số thở dưới 10 lần/phút, không gặp bệnh nhân $\mathrm{SpO}_{2}<90 \%$. 


\section{BÀN LUÂN}

Kết quả nghiên cứu cho thấy, thời gian giải cứu cơn đau đầu tiên ngắn hơn đáng kể ở nhóm Ropivacain $(11,62 \pm 3,80$ giờ) so với nhóm Ropivacain+ Dexamethasone $(19,04 \pm 4,20$ giờ) ( $p<0,001)$, tương tự như tác giả Gupta[7]. Tại sao dexamethasone kéo dài thời gian gây tê vùng là một chủ đề được thảo luận nhiều. Steroid gây ra một mức độ co mạch, vì vậy một giả thuyết cho rằng thuốc hoạt động bằng cách làm giảm sự hấp thu thuốc gây tê. Một giả thuyết hấp dấn hơn cho rằng dexamethasone làm tăng hoạt động của các kênh kali ức chế trên sợi C cảm thụ (thông qua các thụ thể glucocorticoid), do đó làm giảm hoạt động của chúng.

Tất cả bệnh nhẩn đều được hướng dẫn cách sử dụng và ghi lại thang điểm tương tự hình ảnh (VAS) cho cả đau thành bụng và đau nội tạng. Chúng tôi tiến hành so sánh điểm đau VAS -S và VAS-V giữa 2 nhóm tai các thời điểm theo dõi trong 24 giờ sau mổ lấy thai nhân thấy sự khác biệt về điểm số VAS- $S$ và VAS- $V$ của cả hai nhóm là không đáng kể tại các thời điểm 1 giờ, 2 giờ và 4 giờ sau phẫu thuật. Điều này có thể là do tác dụng của gây tê tủy sống được đưa ra ở cả hai nhóm giảm đau đến 4 giờ mối người. Cả hai điểm số VAS- $S$ và VAS -V ở nhóm 1 cao hơn đáng kể so với nhóm 2 ở 8 giờ, 12 giờ, 16 giờ và 24 giờ sau phẫu thuật, do đó cho thây rằng việc bổ sung dexamethasone với ropivacaine trong khối TAP làm giảm đáng kể cơn đau từ cả thành bụng và nội tạng. Kết quả của chúng tôi tương tự như nghiên cứu của tác giả Gupta[7] khi nghiên cứu trên 90 sản phụ sau mổ lấy thai điểm VAS cho cả đau thành bụng và đau nội tạng đều cao hơn đáng kể ở bệnh nhân nhóm Ropivacain so với nhóm Ropivacain+ Dexamethasone tại 8 giờ $(P<0,001), 12$ giờ $(P<0,001)$ và 24 giờ $(\mathrm{P}<0,001)$. Theo nghiên cứu của Abdalla[8] cho thây dexamethasone - bupivacaine trong khối TAP có điểm số đau sau phẫu thuật thấp hơn đáng kể so với bupivacaine ở những bệnh nhân phẫu thuật cắt $u$ bàng quang toàn bộ. Điểm VAS -S tối đa ở nhóm 1 là 12 giờ so với 24 giờ ở nhóm 2, cho thây bệnh nhân nhóm 1 bị đau thành bụng sớm hơn đáng kể so với nhóm 2 . VAS- V ở nhóm 1 cao hơn đáng kể so với nhóm 2 lúc 8 giờ, 12 giờ, 16 giờ và 24 giờ sau phẫu thuâat. Tác dung tích cực này của dexamethasone (8mg) đối với đau nội tạng có thể được giải thích là do tác dụng giảm đau thấp nhưng đáng kể sau khi hấp thu toàn thân.

Lượng morphin tiêu thụ nhóm 1 $(6,02 \pm 2,1 \mathrm{mg})$, nhóm $2(4,58 \pm 1,9 \mathrm{mg})$ kết quả này cũng phù hợp với các nghiên cứu (5 $7 \mathrm{mg})[8,9]$ đã được báo cáo. Việc kết hợp thuốc tê với dexamethason trong gây tề TAP block giúp làm giảm sự tiêu thụ tramadol trong $24 \mathrm{~h}$ sau mổ trên 90 sản phụ sau mổ lấy thai được tác giả Gupta[7] nghiên cứu chỉ ra rằng: tổng lượng tramadol tiêu thu trong 24 giờ cao hơn đáng kể ở nhóm $\mathrm{R}(86,67 \pm 30,55 \mathrm{mg})$ so với nhóm $\mathrm{D}$ $(35,56 \pm 39,54 \mathrm{mg})(p<0,001)$. Ngoài ra, nghiên cứu của chúng tôi cho thấy cả hai nhóm đều có mức độ hài lòng và rất hài lòng là chủ yếu, không có trường hợp nào bệnh nhân không hài lòng. Mức độ hài lòng phụ thuộc vào hiệu quả giảm đau cũng như các tác dụng không mong muốn. Cả 2 nhóm đều có mức độ hài lòng và rất hài lòng là chủ yếu, không có trường hợp nào bệnh nhân không hài lòng. Nhóm 2 có tị lệ rất hài lòng và hài lòng lần lượt là $90 \%$ và $10 \%$ trong khi đó nhóm 1 có tỉ lệ hài lòng $80 \%$ và rất hài lòng là $20 \%$, sự khác biệtnày có ý nghĩa thống kê với $p<0,05$. Nghiên cứu của Costello cho thây sự hài lòng của bệnh nhân với TAP block là rất cao, đều đạt 9 điểm.

Kết quả nghiên cứu của chúng tôi tỷ lệ nôn và buồn nôn ở nhóm 1 và nhóm 2 lần lượt là $20 \%$ và $4 \%$. Trong nghiên cứu của chúng tối các yếu tố liên quan đến nguy cơ buồn nôn và nôn như; giới (tất cả đều là giới nữ), tiền sử hút thuốc (không có bệnh nhân nào) và say tàu xe, sử dụng thuốc trong gây tê và thời gian phẫu thuật là tương đối đồng nhất giữa hai nhóm, điều này tạo điều kiện cho việc so sánh ảnh hưởng của thuốc dexamethasone giữa 2 nhóm chính xác hơn. Điều này làm nổi bật tác dụng chống nôn của dexamethasone ( $8 \mathrm{mg}$ ) thông qua tác động trung tâm trực tiếp tại nhân của đường đơn độc, tương tác với chất dẫn truyền thần kinh serotonin và protein thụ thể tachykinin NK1 và NK2, và alpha adrenaline duy trì các chức năng sinh lý bình thường của các cơ quan và hệ thống, điều hòa vùng dưới đồi-tuyến yên-tuyến thượng thận, sau sự hấp thụ toàn thân của nó. Điểm số buồn nôn giảm cũng có thể do giảm đau tốt hơn và giảm tiêu thụ morphin ở nhóm 2 .

\section{KẾT LUẬN}

Thời gian giải cứu cơn đau đầu tiên ngắn hơn đáng kể ở nhóm $1(11,01 \pm 3,62$ giờ) so với nhóm $2(18,54 \pm 4,15$ giờ $)(p<0,005)$.

Tổng nhu cầu morphin trong 24 giờ đầu sau phẫu thuật cao hơn đáng kể ở nhóm $1(5,62 \pm$ $2,1 \mathrm{mg})$ so với nhóm $2(4,07 \pm 1,9 \mathrm{mg})(p<0,005)$.

Điểm số VAS- $S$ và VAS- $V$ của cả hai nhóm khác nhau không đáng kể tại các thời điểm 1 giờ, 2 giờ và 4 giờ sau phẫu thuật, tuy nhiên ở 
nhóm 1 cao hơn đáng kể so với nhóm 2 tại các thời điểm 8 giờ, 12 giờ, 16 giờ và 24 giờ sau phẫu thuật.

Nhóm 2 có tỉ lê rất hài lòng và hài lòng lần lượt là $90 \%$ và $10 \%$, nhóm 1 lần lượt tương ứng là $80 \%$ và $20 \%, \mathrm{p}<0,05$.

Tỷ lệ nôn ở nhóm 1 chiếm $20 \%$ cao hơn nhiều so với nhóm 2 chỉ chiếm $4 \%, p<0,05$.

Các chỉ số lâm sàng liên quan đến tuần hoàn trong giới hạn bình thường và tương đương nhau giữa hai nhóm ở các thời điểm 1 giờ, 2 giờ , 4 giờ nghiên cứu.

Nhịp tim, HA trung bình lúc 8 giờ, 12 giờ, 16 giờ và 24 giờ sau phẩu thuật ở nhóm 1 cao hơn đáng kể so với bệnh nhân nhóm $2(p<0,05)$.

Các chỉ số lâm sàng liên quan đến hô hấp trong giới hạn bình thường và tương đương nhau giữa hai nhóm ở tất cả các thời điểm nghiên cứu.

Trong nghiên cứu của chúng tôi không gặp bất kỳ tai biến nào liên quan đến gây tê TAP block.

\section{TÀl LIỆ THAM KHẢO}

1. B. Richez, L. Ouchchane, A. Guttmann và các cộng sự. (2015), "The Role of Psychological Factors in Persistent Pain After Cesarean Delivery", J Pain, 16(11), tr. 1136-46.
2. Uma Hariharan và Vinoth Natarajan (2017), "Rectus Sheath Block and Transversus Abdominis Plane Block for Pain Relief after Cesarean Section".

3. Zhirajr Mokini Poturljan (2011), Ultrasound Blocks for the Anterior Abdominal Wall Principles and Implementation for Adult and Pediatric Surgery. 2011 Edition.

4. P. Hebbard (2015), "TAP block nomenclature", Anaesthesia, 70(1), tr. 112-3.

5. C. Pehora, A. M. Pearson, A. Kaushal và các cộng sự. (2017), "Dexamethasone as an adjuvant to peripheral nerve block", Cochrane Database Syst Rev, 11(11), tr. Cd011770.

6. A. Zorrilla-Vaca và J. Li (2018), "Dexamethasone Injected Perineurally is More Effective than Administered Intravenously for Peripheral Nerve Blocks: A Meta-Analysis of Randomized Controlled Trials", Clin J Pain, 34(3), tr. 276-284.

7. A. Gupta, A. Gupta và N. Yadav (2019), "Effect of dexamethasone as an adjuvant to ropivacaine on duration and quality of analgesia in ultrasound-guided transversus abdominis plane block in patients undergoing lower segment cesarean section - A prospective, randomised, single-blinded study", Indian J Anaesth, 63(6), tr. 469-474.

8. P. L. Petersen, O. Mathiesen, P. Stjernholm và các cộng sự. (2013), "The effect of transversus abdominis plane block or local anaesthetic infiltration in inguinal hernia repair: a randomised clinical trial", Eur J Anaesthesiol, 30(7), tr. 415-21.

\section{ĐĂC ĐIỂM LÂM SÀNG CỦA THAI PHỤ SẨY THAI LIÊN TIẾP KHÔNG Rõ NGUYÊN NHÂN MANG GEN METHYLENETETRAHYDROFOLATE REDUCTASE BỆNH LÝ}

\section{TÓM TẮT}

Nguyên nhân sẩy thai liên tiếp rất phức tạp và khó xác định, trong đó đa hình đơn gen MTHFR bệnh lý (C677T, A1298C) là một nguyên nhân mới cần tìm hiểu. Nghiên cứu nhằm: Xác định mối liên quan giữa MTHFR và bệnh lý sảy thai liên tiếp; Mô tả đặc điểm lâm sàng của những thai phụ có tiên sử sảy thai liên tiếp mang gen MTHFR (C677T và A1298C) bệnh lý. Đây là 1 nghiên cứu bệnh- chứng, 2 nhóm đều được xác định kiểu gen của gen MTHFR C677T/A1298C bằng phương pháp PCR. Nghiên cứu thu được 43 thai phụ thuộc nhóm bệnh và 30 thai phụ thuộc nhóm chứng. Thời điểm thai sẩy trung bình trong tiền sử của nhóm mang kiểu gen bệnh lý là 8,47 tuân. MTHFR

\footnotetext{
${ }^{1}$ Trường Đại học Y Hà Nội

${ }^{2}$ Bệnh viện Đa khoa Quốc Tế Vinmec Times City

Chịu trách nhiệm chính: Lê Thị Anh Đào

Email: leanhdao1610@gmail.com

Ngày nhận bài: 10.8.2021

Ngày phản biên khoa họ: 11.10.2021

Ngày duyệt bài: 20.10.2021
}

\section{Lê Thị Anh Đào', Nguyễn Thị Hằng ${ }^{2}$}

C677T làm tăng nguy cơ xuất hiện triệu chứng doa sẩy thai trong 3 tháng đâu $(p=0,043)$. Kết luận: Đà hình đơn gen MTHFR C677T tăng xuất hiện triệu chứng doa sẩy thai trong 3 tháng đâu.

Tư khoá: MTHFR C677T, MTHFR A1298C, sẩy thai liên tiếp không rõ nguyên nhân

\section{SUMMARY \\ CLINICAL FEATURES OF UNEXPLAINED RECURRENT PREGNANCY LOSS WOMEN CARRYING ABNORMAL MTHFR POLYMORPHISM GENE}

Unexplained RPL has been a challenging issue in diagnosis. Methylenetetrahydrofolate reductase (MTHFR) gene polymorphisms (C677T, A1298C) are believed to be risk of unexplained recurrent pregnancy loss. This study aims to describe the clinical signs of women with recurrent pregnancy loss and MTHFR polymorphism gene. This is a case-control study was performed on 2 groups. Both two groups were evaluated for the presence of MTHFR gene polymorphisms by PCR technique. Result: A total of 43 cases and 30 controls were identified. The gene 